Współpraca ortodontycznologopedyczna w skojarzonym leczeniu ortodontycznochirurgicznym Opis przypadku

\section{Orthodontic and speech therapy cooperation in combined orthodontic and surgical treatment Case report}

\author{
Maria Orzelska-Blomberg1 ABDEF (ORCID ID: 0000-0002-1283-2846) \\ Agnieszka Banaszkiewicz ${ }^{2}$ ABDEF (ORCID ID: 0000-0001-5630-7237) \\ Anna Walencik-Topiłko 3 DEF (ORCID ID: 0000-0002-5443-6673) \\ Bogna Racka-Pilszak ${ }^{4}$ G (ORCID ID: 0000-0002-3709-3576)
}

\author{
Wkład autorów: $\mathbf{A}$ Plan badań $\mathbf{B}$ Zbieranie danych $\mathbf{C}$ Analiza statystyczna $\mathbf{D}$ Interpretacja danych \\ $\mathbf{G}$ Redagowanie pracy $\mathbf{F}$ Wyszukiwanie piśmiennictwa \\ Authors' Contribution: A Study design B Data Collection C Statistical Analysis D Data Interpretation \\ $\mathbf{E}$ Manuscript Preparation $\mathbf{F}$ Literature Search \\ 1,4 Zakład Ortodoncji, Gdański Uniwersytet Medyczny \\ Department of Orthodontics, Medical University of Gdansk \\ ${ }^{2,3}$ Katedra Logopedii, Wydział Filologiczny, Uniwersytet Gdański \\ Faculty of Languages, Department of Logopaedics, University of Gdańsk
}

\section{Streszczenie}

Ocena przebiegu procesów rozwojowo-czynnościowych układu stomatognatycznego należy do specjalistów z dziedziny logopedii i ortodoncji. Coraz częściej obserwuje się wspólne projekty naukowe, jak też i działania praktyczne specjalistów z obu tych grup. W literaturze przedmiotu można spotkać nieliczne doniesienia na temat leczenia pacjentów z poważnymi zaburzeniami szkieletowymi w zespole ortodontyczno-chirurgicznym przy współudziale logopedów. Cel. Głównym celem artykułu bylo ukazanie na podstawie studium przypadku pacjentki z wadą szkieletową i wadą wymowy specyfiki współpracy ortodontycznologopedycznej. Dodatkowo zaprezentowano szereg ćwiczeń, tradycyjnie zaliczanych do logopedycznych, które można

\begin{abstract}
Specialists in the field of speech therapy and orthodontics evaluate developmental and functional processes of the stomatognathic system. Joint research projects and practical activities between specialists in these fields are more and more often observed. There are only few literature reports on the treatment of patients with severe skeletal disorders by orthodontic and surgical teams with the cooperation of speech therapists. Aim. The main aim of the article was to present principles of cooperation between orthodontists and speech therapists based on a case report of a female patient with a skeletal defect and speech defect. Additionally, exercises that are traditionally classified as speech therapy were presented and they can be recommended to adult
\end{abstract}

\footnotetext{
${ }^{1}$ Lek. dent., dr n. med., asystent, w trakcie specjalizacji z ortodoncji / DDS, PhD, Postgraduate Orthodontic Resident

2 Dr n. hum., adiunkt / PhD

${ }^{3}$ Dr n. hum., adiunkt / PhD

${ }^{4}$ Dr n. med., Kierownik Zakładu Ortodoncji / DDS, PhD, Associate Professor, Head of the Department of Orthodontics
}

Dane do korespondencji/Correspondence address:

Al. Zwycięstwa 42c

80-210 Gdańsk

e-mail: orzelska@gumed.edu.pl 
zalecić pacjentom dorosłym przed i po operacji ortognatycznej. Opisano metody ćwiczeń w taki sposób, aby mogli to robić nie tylko logopedzi, ale również ortodonci. Materiał i metody. Wykorzystany materiał stanowiła dokumentacja ortodontyczna oraz logopedyczna na podstawie studium przypadku zebrana w latach 2015-18 w Poradni Ortodoncji UCS GUMed. Zebrany materiał empiryczny został przeanalizowany przez dwóch logopedów i dwóch ortodontów. Wyniki. W przypadku zaprezentowanego pacjenta korelacja leczenia ortodontycznochirurgicznego z terapią logopedyczną okazała się bardzo korzystna. Zespół ortodontyczno-logopedyczny powinien zlecić odpowiednio dobrane ćwiczenia, by pomóc pacjentowi wypracować umiejętność prawidłowego oddychania, połykania i żucia. W okresie przed operacją właściwe jest wprowadzenie ćwiczeń oddechowych, motoryki żuchwy, warg i język. Po operacji dołączyć należy ćwiczenia odgryzania, żucia, połykania i prawidłowego ułożenia języka w pozycji spoczynkowej, niekiedy korektę artykulacji. Wnioski. W przypadku współwystępowania wady szkieletowej z wadą wymowy leczenie ortodontyczne skorelowane z terapią logopedyczną ma na celu stabilizację wyników leczenia ortodontycznego oraz szybszy powrót do wykonywania poprawnie fizjologicznych czynności narządu żucia. (Orzelska-Blomberg M, Banaszkiewicz A, Walencik-Topiłko A, Racka-Pilszak B. Współpraca ortodontyczno-logopedyczna w skojarzonym leczeniu ortodontyczno-chirurgicznym. Opis przypadku. Forum Ortod 2019; 15: 140-52).

Nadesłano: 05.12.2018

Przyjęto do druku: 04.04.2019

Słowa kluczowe: terapia logopedyczna, ćwiczenia języka i warg, współpraca ortodontyczno-logopedyczna, prognatyzm żuchwy, wada szkieletowa, reedukacja pozabiegowa

\section{Wstęp}

Ocena przebiegu procesów rozwojowo-czynnościowych układu stomatognatycznego $(1,2,3$, 4) należy do specjalistów z dziedziny logopedii i ortodoncji. Coraz częściej obserwuje się ich wspólne projekty naukowe i działania praktyczne, które dotyczą leczenia dzieci z zaburzeniami mowy i wadami zgryzu. Na podstawie prezentowanego studium przypadku pokazano możliwość takiej interdyscyplinarnej współpracy na trochę innym polu - w pracy z dorosłymi pacjentami zakwalifikowanymi do zabiegów ortognatycznych.

W literaturze przedmiotu można spotkać nieliczne doniesienia na temat leczenia pacjentów z poważnymi zaburzeniami zgryzowymi i szkieletowymi w zespole ortodontyczno-chirurgicznym przy współudziale logopedów. W artykule poglądowym Hassan i wsp. wskazali zaledwie 9 takich tekstów opublikowanych w latach 1966-2006, przy czym prezentowane grupy badawcze były nieliczne i niejednorodne (5). patients before and after an orthognathic procedure. Exercises were described so as they could be recommended by orthodontists as well, and not only speech therapists. Material and methods. The material used included orthodontic and speech therapy documentation prepared on the basis of a case study collected in 2015-2018 at the Outpatient Clinic of Orthodontics, UCS GUMed. Collected empirical material was analysed by two speech therapists and two orthodontists. Results. Regarding this patient, correlation between orthodontic and surgical treatment and speech therapy was extremely beneficial. An orthodontic and speech therapy team should recommend specifically tailored exercises to help the patient develop functions of proper breathing, swallowing and chewing. In the period before the surgery it is recommended to introduce respiratory exercises, exercises for the motor functions of the mandible, lips, and tongue. After the surgery it is recommended to add exercises to practice biting off, chewing, swallowing and a correct position of the tongue at rest, sometimes exercises to improve articulation. Conclusions. When a skeletal defect coexists with a speech defect orthodontic treatment correlated with speech therapy is aimed to maintain outcomes of orthodontic treatment and to help recovery of correct performance of physiological functions of the masticatory organ. (Orzelska-Blomberg M, Banaszkiewicz A, Walencik-Topiłko A, Racka-Pilszak B. Orthodontic and speech therapy cooperation in combined orthodontic and surgical treatment. Case report. Orthod Forum 2019; 15: 140-52).

Received: 05.12.2018

Accepted: 04.04.2019

Key words: speech therapy, exercises for the tongue and lips, orthodontic and speech therapy cooperation, mandibular prognathism, skeletal defect, postoperative reeducation

\section{Introduction}

Specialists in the field of speech therapy and orthodontics evaluate developmental and functional processes of the stomatognathic system $(1,2,3,4)$. Their joint research projects and practical activities regarding treatment of children with speech impairments and malocclusions are more and more often observed. The presented case study shows that such interdisciplinary cooperation is possible in a slightly different field - working with adult patients eligible for orthognathic procedures.

There are only few reports on the treatment of patients with severe malocclusions and skeletal disorders by orthodontic and surgical teams with the cooperation of speech therapists. In their review article Hassan et al. indicated only 9 such texts published in the years 19662006, and research groups presented were few and heterogeneous (5). 
Należy pamiętać, że takie dysfunkcje, jak nieprawidłowe oddychanie, połykanie, żucie, gryzienie, ułożenie języka w spoczynku, a także obniżenie sprawności języka i warg mogą korelować zarówno $\mathrm{z}$ wadami wymowy, jak i zaburzeniami zgryzowymi $(1,3,6,7,8,9,10)$.

\section{Cel}

Głównym celem artykułu było przedstawienie studium przypadku pacjentki z wadą szkieletową i wadą wymowy, poddanej terapii ortodontyczno-logopedyczno-chirurgicznej, oraz zwrócenie uwagi na specyfikę i charakter współpracy ortodonty z logopedą w opisanym postępowaniu leczniczoterapeutycznym. Zaprezentowano także ćwiczenia tradycyjnie zaliczane do logopedycznych, które zarówno logopedzi, jak i ortodonci (np. gdy nie ma możliwości współpracy z logopedą) mogą zalecić pacjentom dorosłym przed i po operacji ortognatycznej.

\section{Materiał i metody}

Wykorzystany materiał stanowiły dokumentacja ortodontyczna i logopedyczna sporządzona na podstawie studium przypadku. W skład materiału badawczego wchodziły modele diagnostyczne, zdjęcia rentgenowskie cefalometryczne i pantomograficzne - oraz wyniki badania klinicznego zewnątrz- i wewnątrzustnego. Zebrane materiały dotyczyły pacjentki, która została poddania terapii ortodontycznej oraz logopedycznej w Poradni Ortodoncji UCS GUMed w latach 2015-2018. Przedstawiono przebieg leczenia ortodontycznego we współpracy ortodontycznologopedyczno-chirurgicznej. Ze strony logopedycznej przeanalizowano kartę diagnozy mowy, kartę wywiadu logopedycznego oraz notatki z poszczególnych zajęć terapeutycznych. Zebrany materiał empiryczny został przeanalizowany przez dwóch logopedów i dwóch ortodontów.

\section{Opis przypadku}

\section{Opis ortodontyczny}

Pacjentka, lat 17, zgłosiła się lutym 2015 roku do Poradni Ortodoncji UCS GUMed w celu leczenia wady zgryzu. Na podstawie badania klinicznego oraz badań dodatkowych została postawiona diagnoza ortodontyczna. Wykazała ona zaburzenie o charakterze szkieletowym: przodożuchwie morfologiczne, zgryz krzyżowy boczny obustronny, szparowatość w łuku górnym, stłoczenie siekaczy dolnych (Ryc. 1. a-j).

Poinformowano pacjentkę o różnych możliwościach leczenia, w tym leczenia zespołowego ortodontycznochirurgicznego. Przedstawiono plan, który obejmował usunięcie zębów 18, 28, 38, 48, dekompensację wady zgryzu za pomocą aparatów stałych cienkołukowych, konsultację i leczenie logopedyczne oraz konsultację i leczenie chirurgiczne (wykonanie zabiegu ortognatycznego).
It should be remembered that such dysfunctions as abnormal breathing, swallowing, chewing, biting, tongue resting position and reduced competence of tongue and lips may correlate with both speech defects and malocclusions $(1,3,6,7,8,9,10)$.

\section{Aim}

The main aim of the article was to present a case study of a female patient with skeletal and speech defects, undergoing orthodontic-speech therapy-surgical therapy, and to draw attention to the character and nature of cooperation between an orthodontist and speech therapist in a described protocol consisting of treatment and therapy. Exercises that are traditionally classified as speech therapy are presented, and they can be recommended by speech therapists and orthodontists (e.g. when it is not possible to cooperate with a speech therapist) to adult patients before and after an orthognathic procedure.

\section{Material and methods}

The material used included orthodontic and speech therapy documentation prepared on the basis of a case study. The study material consisted of diagnostic models, X-ray images - cephalometric and pantomographic images - as well as results of an extra- and intraoral clinical examination. The collected material concerned a female patient who underwent orthodontic treatment and speech therapy at the Outpatient Clinic of Orthodontics, UCS GUMed in the period 2015-2018. The course of orthodontic treatment in orthodontic-speech therapy-surgical cooperation is presented. Regarding speech therapy, the speech diagnosis card, the speech therapy history card and notes from individual therapeutic classes were analysed. Collected empirical material was analysed by two speech therapists and two orthodontists.

\section{Case report Orthodontic description}

Female patient, aged 17, came to the Outpatient Clinic of Orthodontics, UCS GUMed in February 2015 to treat a malocclusion. An orthodontic diagnosis was made based on a clinical examination and additional tests. It showed skeletal abnormalities: morphological mandibular anteroposition, lateral bilateral crossbite, gaps in the upper arch, crowding of lower incisors (Fig. 1. a-j).

The patient was informed about various treatment options, including combined orthodontic and surgical treatment. A plan was presented, and it included removal of teeth 18 , $28,38,48$, decompensation of a malocclusion with thin fixed archwires, speech therapy consultation and treatment, as well as a surgical consultation and treatment (an orthognathic procedure). 
Orthodontic and speech therapy cooperation in combined orthodontic and surgical treatment. Case report
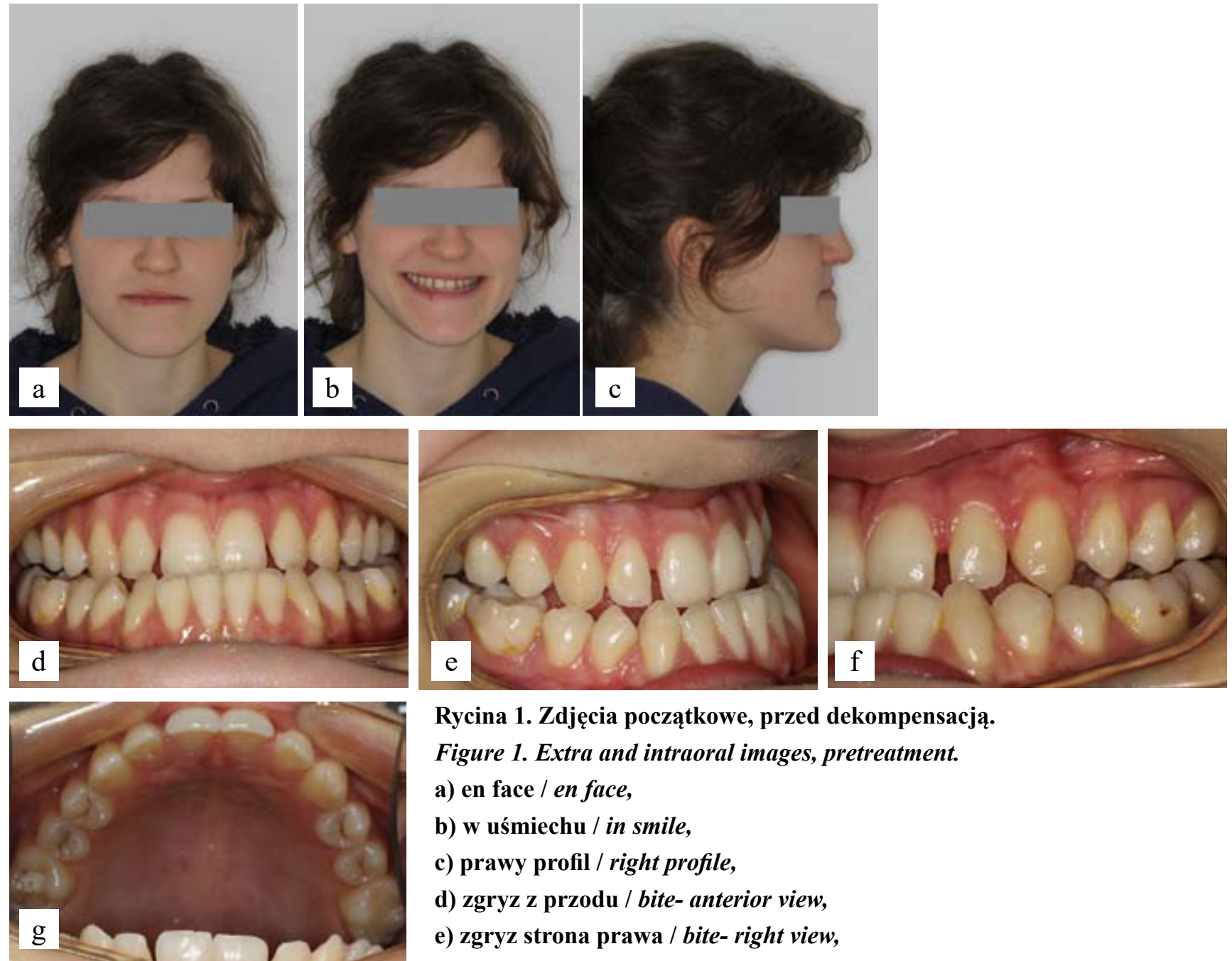

Rycina 1. Zdjęcia początkowe, przed dekompensacją.

Figure 1. Extra and intraoral images, pretreatment.

a) en face / en face,

b) w uśmiechu / in smile,

c) prawy profil / right profile,

d) zgryz z przodu / bite- anterior view,

e) zgryz strona prawa / bite- right view,

f) zgryz strona lewa / bite- left view,

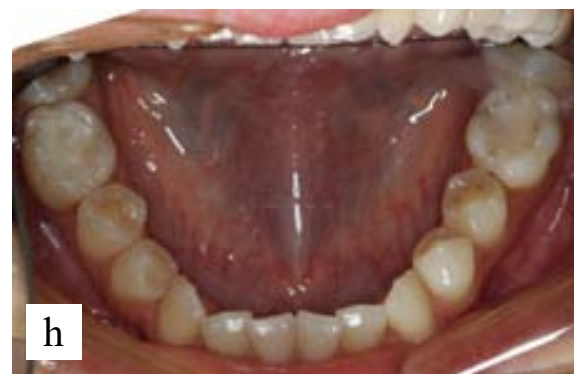

g) górny luk zębowy / upper dental arch,

h) dolny luk zębowy / lower dental arch,

i) rtg pantomograficzne / panoramic $X$-ray,

j) telertg boczne glowy/ cephalometric $X$-ray.
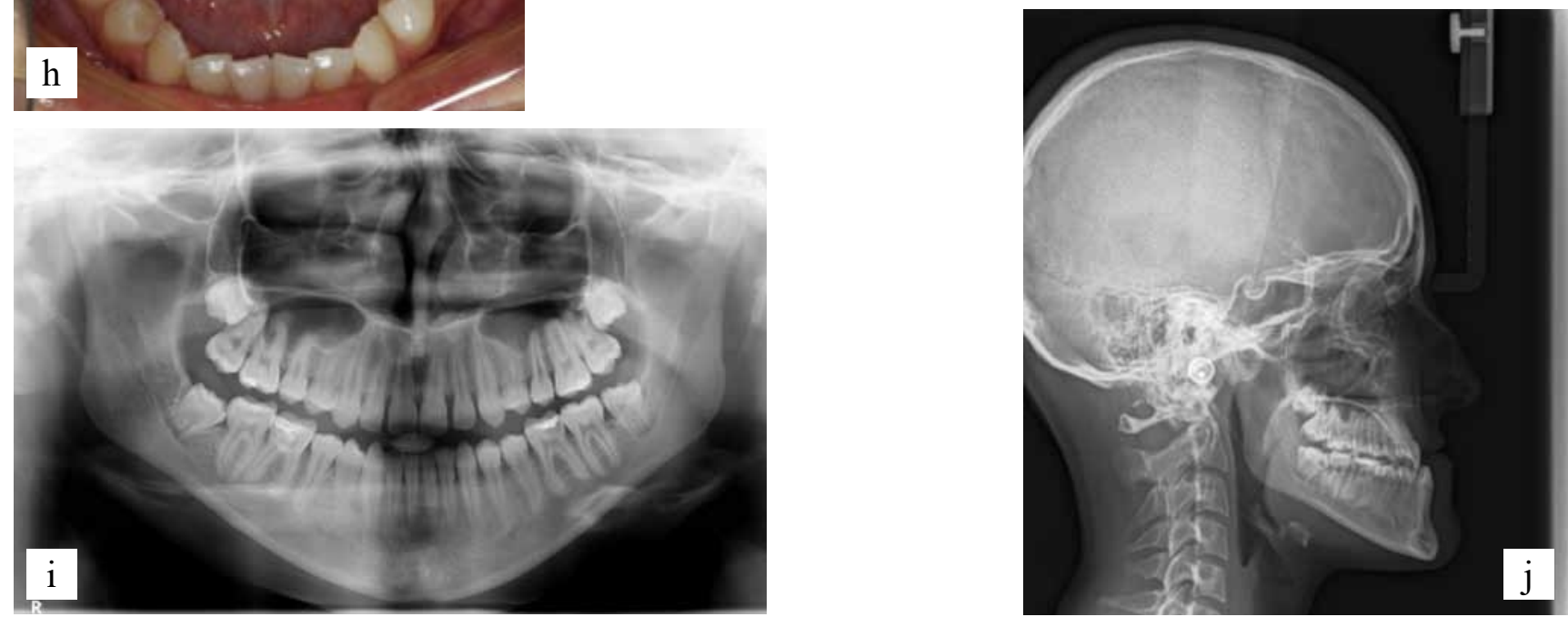

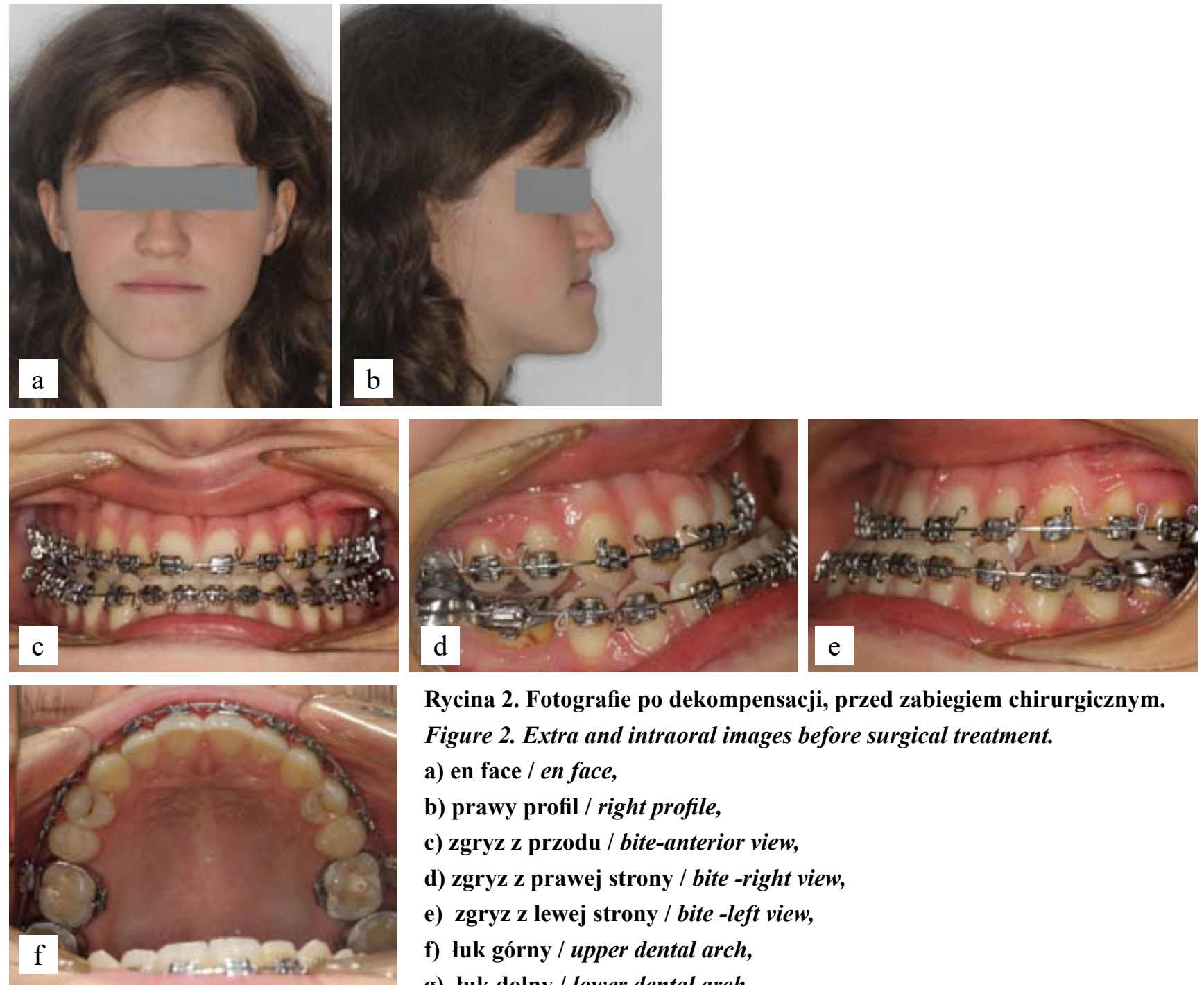

Rycina 2. Fotografie po dekompensacji, przed zabiegiem chirurgicznym. Figure 2. Extra and intraoral images before surgical treatment.

a) en face / en face,

b) prawy profil / right profile,

c) zgryz z przodu / bite-anterior view,

d) zgryz z prawej strony / bite -right view,

e) zgryz z lewej strony / bite -left view,

f) luk górny / upper dental arch,

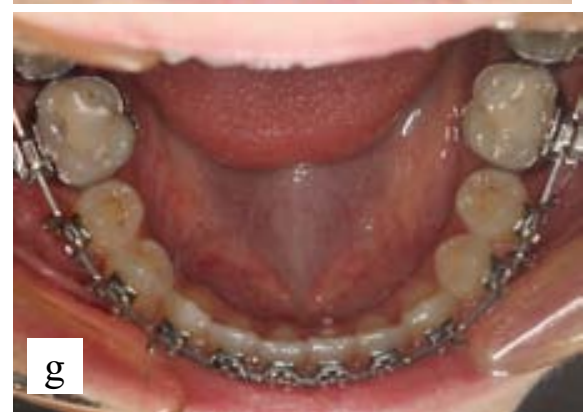

g) luk dolny / lower dental arch,

h) rtg pantomograficzne / panoramic $X$-ray,

i) telertg boczne glowy/ cephalometric $X$-ray.
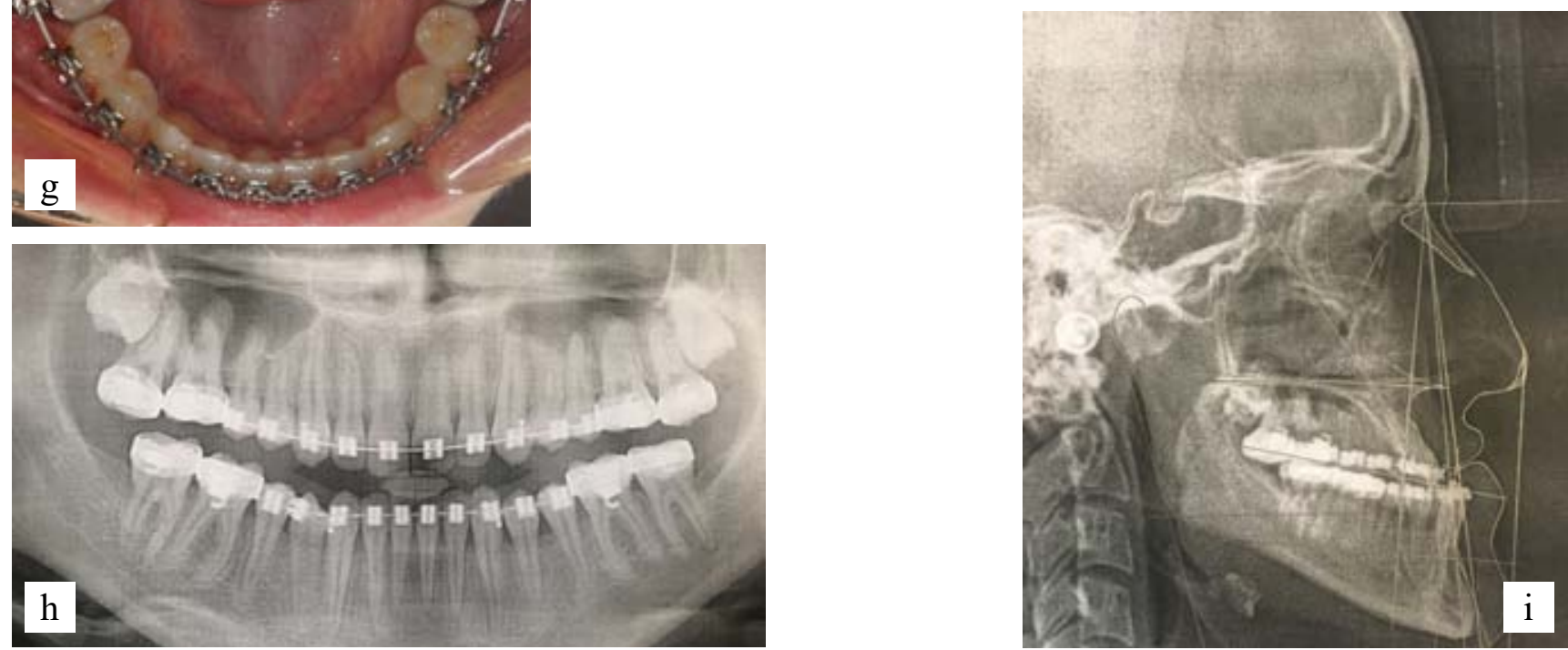

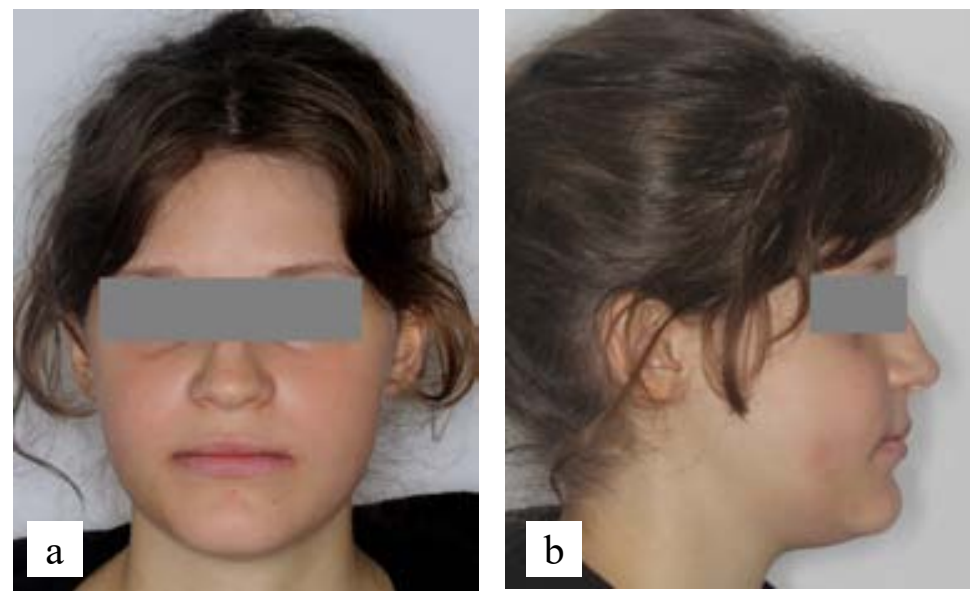

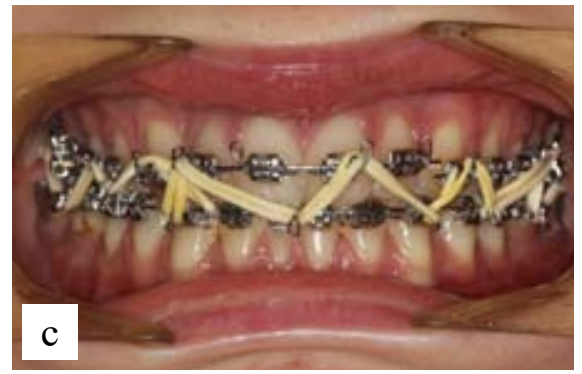

Rycina 3. Fotografie 3 tygodnie po zabiegu.

Figure 3. Extra and intraoral images postsurgery.

a) en face / en face,

b) prawy profi / right profile,

c) zgryz z przodu / bite -anterior view.
Konwencjonalną terapię ortodontyczną rozpoczęto $w$ marcu 2015 roku, zaczynając od założenia aparatu stałego cienkołukowego górnego w slocie 0.22 Roth i łuku 0.14 NiTi. W kolejnym miesiącu założono aparat dolny, również w slocie 0.22 Roth, łuk 0.14 NiTi oraz zacementowano pierścienie na zęby $17,27,37,47$. Po zakończeniu fazy niwelizacji na łuku 0.16 x 0.22 Copper Niti, założono łuki 0.16 x $0.22 \mathrm{SS}$, na których domknięto powstałe szpary w łuku dolnym. Pacjentka została skierowana na zabieg na łukach $0.19 \mathrm{x}$ 0.25 SS (łuki operacyjne). Po każdej wizycie u ortodonty następowała kontrola logopedycznej terapii przedzabiegowej. Należy podkreślić, że na każdym etapie leczenia pacjentka bardzo dobrze współpracowała z ortodontą.

Faza dekompensacji trwała 1,5 roku (Ryc. 2. a-i). Pacjentka zdecydowała się na zabieg w Warszawie w Wojskowym Instytucie Medycznym na Oddziale Klinicznym Chirurgii Czaszkowo-Szczękowo-Twarzowej. Operacja odbyła się we wrześniu 2016 roku i wykonano wówczas osteotomię segmentarną szczęki oraz osteotomię strzałkową gałęzi żuchwy metodą Obwegesera w modyfikacji Dal Ponta. Po zabiegu zastosowano rutynowe unieruchomienie międzyszczękowe (Ryc. 3. a-c).

Leczenie ortodontyczne pooperacyjne trwało 9 miesięcy i polegało na: stabilizacji odłamów przez coraz rzadsze noszenie wyciągów międzyszczękowych; ostatecznej korekcji nagryzu pionowego i poziomego; uzyskaniu prawidłowych kontaktów w odcinkach bocznych oraz drobnych korektach położenia pojedynczych zębów. Przed zdjęciem aparatów zadecydowano o zastosowaniu stałej retencji w łuku górnym i dolnym (Dentaflex) oraz retencji zdejmowanej w postaci płytki Hawleya. Niestety, pacjentka zdecydowała się na szybsze zakończenie fazy aktywnej leczenia, niż zostało to zalecone (Ryc. 4. a-j).
Conventional orthodontic treatment started in March 2015 , and a fixed thin archwire was placed in the 0.22 Roth slot with a $0.14 \mathrm{NiTi}$ archwire. In the next month a lower appliance was placed, also in the 0.22 Roth slot, with a 0.14 NiTi archwire, and rings were cemented on teeth $17,27,37$, 47. After completion of the levelling phase on a $0.16 \times 0.22$ Copper Niti archwire $0.16 \times 0.22$ SS archwires were placed in order to close gaps formed in the lower arch. The patient was referred for a procedure on $0.19 \times 0.25 \mathrm{SS}$ arches (surgical arches). After each visit at the orthodontist's office there was a follow-up with a speech therapist before the procedure. It should be emphasised that at each stage of treatment the patient cooperated with the orthodontist very well.

The decompensation phase lasted 1.5 years (Fig. 2. a-i). The patient decided to undergo surgery in Warsaw, at the Military Institute of Medicine, Clinical Ward of Craniomaxillofacial Surgery. The surgery took place in September 2016 and maxillary segmental osteotomy and sagittal osteotomy of the mandibular ramus using the Obwegeser's technique in the Dal Ponta modification was performed. After the procedure routine intermaxillary immobilisation was applied (Fig. 3. a-c).

Postoperative orthodontic treatment lasted 9 months and consisted of: stabilisation of fragments by wearing intermaxillary traction at longer intervals; final correction of overjet and overbite; obtaining normal contact in lateral sections and minor corrections of positions of individual teeth. Before removing appliances, a decision was made to use a fixed retainer in the upper and lower arch (Dentaflex) and a removable retainer in the form of a Hawley appliance. Unfortunately, the patient decided to terminate the active phase of treatment earlier than it had been recommended (Fig. 4. a-j). 

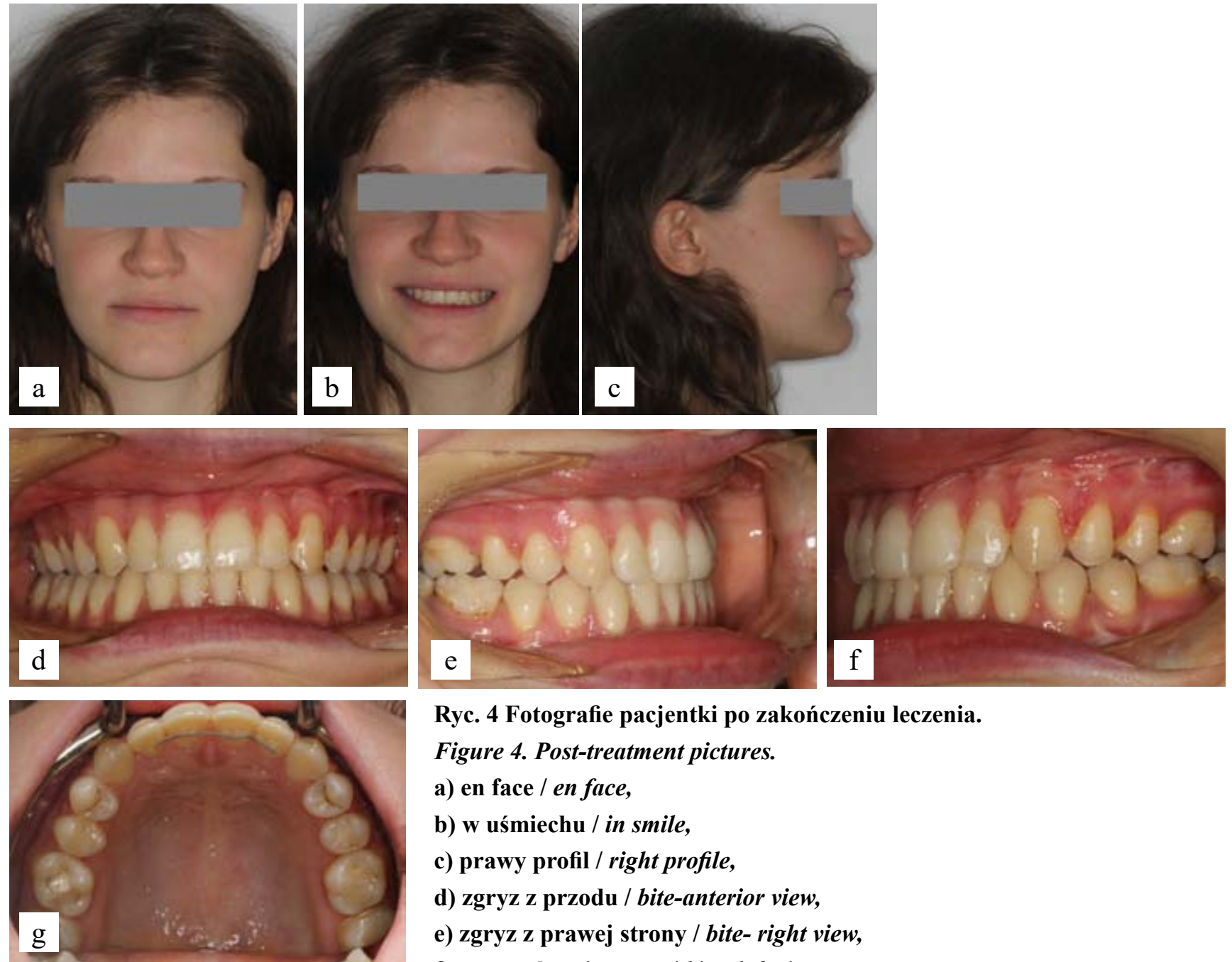

Ryc. 4 Fotografie pacjentki po zakończeniu leczenia.

Figure 4. Post-treatment pictures.

a) en face / en face,

b) w uśmiechu / in smile,

c) prawy profil / right profile,

d) zgryz z przodu / bite-anterior view,

e) zgryz z prawej strony / bite- right view,

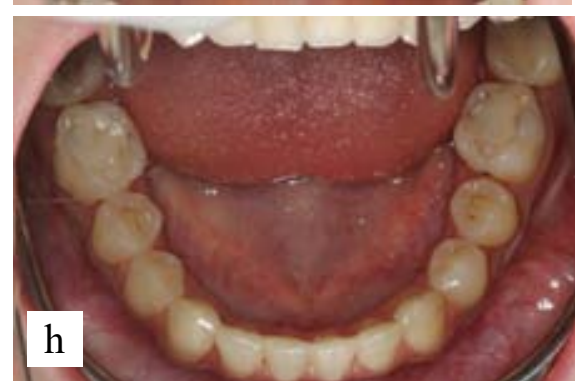

f) zgryz z lewej strony / bite- left view,

g) górny luk zębowy / upper dental arch,

h) dolny luk zębowy / lower dental arch,

i) rtg pantomograficzne / panoramic $X$-ray,

j) telertg boczne glowy / cephalometric $X$-ray.
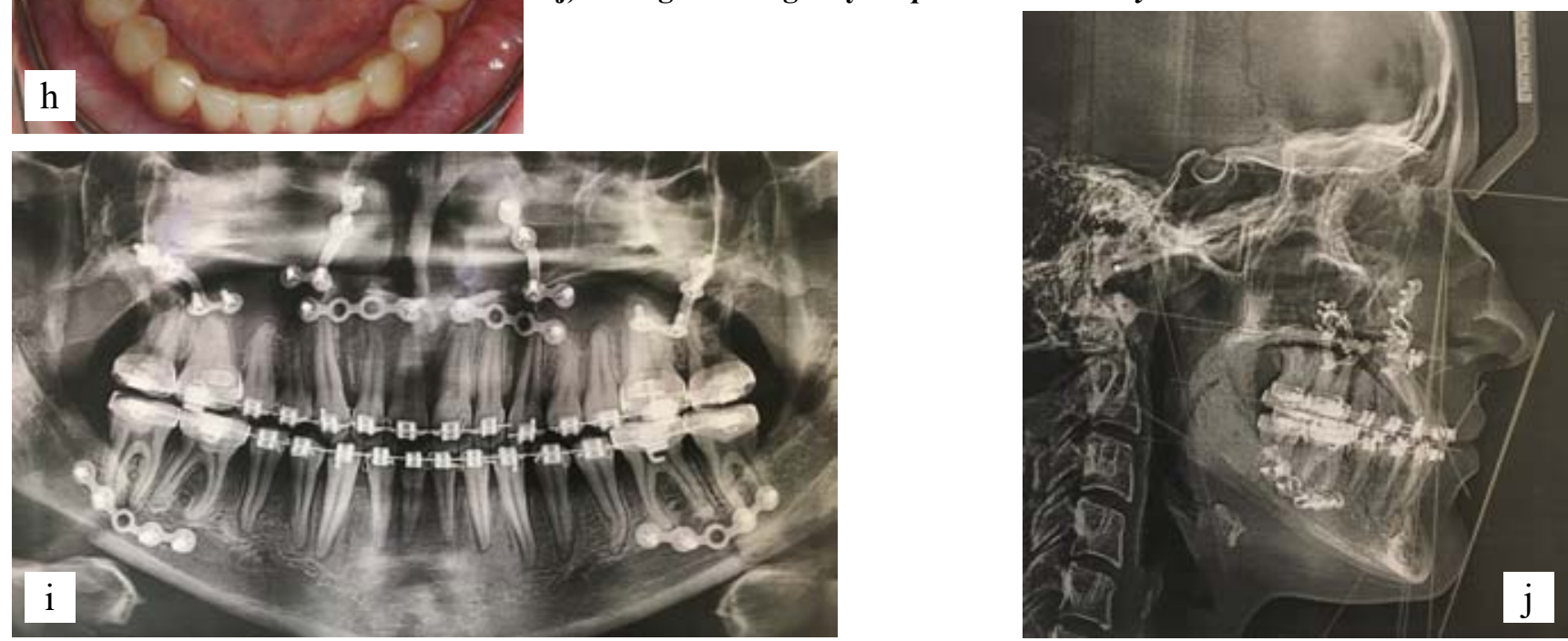


\section{Opis logopedyczny}

\section{Diagnoza logopedyczna przed operacją}

Pacjentka, skierowana przez lekarza ortodontę, zgłosiła się do logopedy w grudniu 2015 roku. Badanie wykazało:

- wymowa pacjentki była w pełni zrozumiała, ale stwierdzono zaburzenie artykulacji polegające na międzyzębowej wymowie głosek t, d, n, s, z, c, d (zapis ortograficzny). Pacjentka nigdy dotąd nie korzystała z terapii logopedycznej;

- $\quad$ właściwy tor oddychania - nosem - przy zamkniętej jamie ustnej i złączonych wargach;

- $\quad$ nieprawidłowe ułożenie języka podczas połykania (infantylne, typu dziecięcego, z tłoczeniem języka na dolne zęby - według opisu Mackiewicza (2));

- $\quad$ nieprawidłowe ułożenie języka w spoczynku (ułożenie na dnie jamy ustnej - pozycja „bardzo niska” według opisu Artese i in. (7))

\section{Terapia logopedyczna}

Ćwiczenia logopedyczne prowadzono zarówno przed, jak i po operacji. Przed operacją miały na celu wypracować świadomość czucia ułożenia narządów artykulacyjnych oraz zwrócić uwagę na prawidłowy sposób oddychania. Ich wprowadzenie jeszcze przed zmianą warunków morfologicznych sprzyja skróceniu czasu terapii po operacji. Zalecenia po operacji zawierały intensyfikację ćwiczeń przedoperacyjnych oraz ćwiczenia pionizacji języka, motoryki warg, połykania, żucia i artykulacji. Wszystkie ćwiczenia pacjentka miała wykonywać również samodzielnie w domu, przed lustrem, codziennie przez kilka minut, 10 razy każde ćwiczenie lub przez ok. 10 sek.

\section{Przed operacja}

Ćwiczenia czucia ułożenia narządów artykulacyjnych (języka i warg):

- masowanie końcem języka podniebienia twardego przy zamkniętych oraz otwartych ustach;

- $\quad$ punktowe dotykanie końcem języka podniebienia twardego przy opuszczonej i nieruchomej żuchwie;

- $\quad$ kląskanie i cmokanie językiem przy opuszczonej i nieruchomej żuchwie;

- uśmiech - „dzióbek” z warg na zmianę;

- $\quad$ przepychanie powietrza między zamkniętymi wargami z zębami (w przedsionku jamy ustnej);

- $\quad$ gwizdanie z wyraźnym uwypukleniem warg;

- zaciskanie i rozluźnianie warg;

- parskanie.

Ćwiczenia oddechowe wykonywane w pozycji siedzącej z wyprostowymi plecami:

- $\quad$ wdech nosem, wydech ustami; wdech i wydech nosem; oddech naprzemienny lewym, potem prawym nozdrzem (zatykanie palcem drugiego nozdrza);

\section{Speech therapy description}

\section{Speech therapy diagnosis before surgery}

The patient, referred by an orthodontist, reported to a speech therapist in December 2015. The examination showed the following:

- the patient's pronunciation was fully understandable, but there was an articulation disorder consisting in interdental pronunciation of sounds $t, d, n, s, z, c, d$ (spelling). The patient had never received speech therapy before;

- $\quad$ proper breathing route - via the nose - with the mouth closed and the lips connected;

- improper tongue position while swallowing (infantile, child type, with tongue thrust onto the lower teeth - according to the Mackiewicz's description (2));

- improper tongue resting position (placement at the bottom of the oral cavity - "very low" position as described by Artese et al. (7)).

\section{Speech therapy}

Speech therapy exercises were conducted both before and after the surgery. Before the surgery, they were aimed to develop awareness of the position of articulatory system organs and to draw attention to the correct breathing route. When they are introduced before the change of morphological conditions, they help shorten treatment duration after the surgery. Postoperative recommendations included intensification of preoperative exercises and exercises for the tongue vertical position, lip motor functions, swallowing, chewing and articulation. The patient was to perform all exercises on her own at home, in front of the mirror, every day for a few minutes, each exercise 10 times or for about 10 seconds.

\section{Before surgery}

Exercises aimed to increase awareness of the position of the articulatory organs (tongue and lips):

- massaging the hard palate with the tongue tip, with the mouth closed and open;

- $\quad$ spot-like touching the hard palate with the tongue tip, with lowered and immobile mandible;

- clicking and smacking with the tongue, with lowered and immobile mandible;

- $\quad$ smiling - making a lip pout alternately;

- pushing air between closed lips with teeth (in the vestibule of the oral cavity);

- $\quad$ whistling with a visible lip pout;

- clenching and relaxing the lips;

- snorting.

Respiratory exercises performed in a sitting position with the back straightened:

- inhalation via the nose, exhalation via the mouth; inhalation and exhalation via the nose; alternating breathing with the left, then with the right nostril (blocking the other nostril with the finger); 
- dmuchanie na płomień świecy ustawionej 20-30 cm od twarzy pacjentki w pozycji centralnej (najpierw przez duży, a następnie mały „dzióbek” z warg);

- dmuchanie j.w., ale przez „rurkę” ułożoną z języka;

- odchylanie wydechem kartki papieru (format A5), trzymanej centralnie przed twarzą.

\section{Po operacji}

Efektywność ćwiczeń wzrosła, ale wystąpił problem ze szczękościskiem. Zastosowano zatem więcej ćwiczeń oddechowych oraz artykulacyjnych, m.in. wymawianie samogłosek z szerokim otwarciem ust.

Do ćwiczeń języka dodano ćwiczenia pionizacji języka:

- przytrzymywanie wafelka (rodzynka, kawałka skórki od chleba, itp.) końcem języka na podniebieniu, z jednoczesnym opuszczaniem i podnoszeniem żuchwy;

- tzw. „garaż” -język przyklejony do podniebienia (lub dotyk końcem języka do wału dziąsłowego), zęby zaciśnięte, wargi zamknięte, oddychanie przez nos.

Do ćwiczeń warg dodano:

- $\quad$ cmokanie, przy utrzymaniu szczęk w pozycji zgryzowej;

- chowanie górnej wargi pod dolną - i odwrotnie - przy szczękach zwartych.

Nauka schematu ułożenia języka w spoczynku - wskazówka dla pacjentki: koniec szerokiego języka należy ułożyć na podniebieniu, za górnymi zębami w okolicy brodawki przysiecznej (7). Ważne, aby to ułożenie nie wiązało się ze zbytnim napięciem mięśniowym, które często występuje podczas wykonywania tej czynności. Pomagają w tym ćwiczenia pionizacji języka, szczególnie opisane wcześniej przytrzymywanie wafelka i „garaż”.

Połykanie śliny - polecenia: zbierz ślinę na język, dotknij końcem języka do podniebienia, zaciśnij zęby, zamknij wargi, naciskając mocno na podniebienie - przełknij (11). Początkowo ćwiczenie połykania można zlecić do wykonywania przed lustrem, z lekko rozchylonymi wargami - tak, by pacjent miał lepszą kontrolę, również wizualną, nad położeniem i pracą swojego języka.

Połykanie wody - po stwierdzeniu, że pacjentka bez wysiłku i napięcia mięśni twarzowych połykała ślinę w warunkach kontrolowanych, zalecono połykanie małej ilości wody według wcześniejszych wskazówek.

Połykanie jedzenia - po stwierdzeniu, że pacjentka bez wysiłku i napięcia mięśni twarzowych połyka wodę w warunkach kontrolowanych, zalecono połykanie małych kęsów pokarmu stałego według przedstawionych wskazówek.

Czas nauki połykania oraz wypracowania autokontroli i automatyzacji właściwego sposobu połykania i ułożenia języka w spoczynku zależy od sprawności narządów mowy, kinestezji oralnej, motywacji i częstości ćwiczeń. Najczęściej u zmotywowanych dorosłych pacjentów trwa od kilku tygodni do kilku miesięcy (12).
- blowing a candle flame placed at $20-30 \mathrm{~cm}$ from the patient's face in a central position (first through a large and then a small "lip pout");

- blowing as above, but through a "tube" from the tongue;

- bending a sheet of paper (A5 format) held centrally in front of one's face, with one's breath.

\section{After surgery}

The effectiveness of exercises increased, but there was a problem with lockjaw. Therefore, more breathing and articulatory exercises were applied, e.g. pronouncing vowels with the mouth wide open.

In addition to tongue exercises, the exercises to practice a vertical position of the tongue were added:

- $\quad$ holding a wafer (raisin, a piece of bread crust, etc.) with the tongue tip on the palate, while lowering and lifting the mandible at the same time;

- so-called "garage" - the tongue touches the palate (or the tongue tip touches the alveolar ridge), clenched teeth, closed lips, breathing via the nose.

The following exercises were added to exercises for lips:

- smocking, while keeping the jaws in the occlusal position;

- $\quad$ hiding the upper lip under the lower lip - and vice versa - with the jaws closed.

Teaching how to place the tongue at rest - a tip for the patient: the tip of the broad tongue should be placed on the palate, behind the upper teeth in the area of the incisive papilla (7). It is important to remember that this position should not be associated with excessive muscle tension, which often occurs during this activity. Exercises for the tongue vertical position, especially exercises with a wafer and "garage" described above are helpful for this.

Saliva swallowing - commands: collect saliva on your tongue, touch the palate with your tongue tip, clench your teeth, close your lips and while pressing firmly on the palate - swallow (11). Initially, the swallowing exercise can be performed in front of the mirror, with the lips slightly apart - so that the patient could have better control, also visual one, over the position and work of their tongue.

Water swallowing - when it was found that the patient had swallowed saliva under controlled conditions without effort and tension of the facial muscles, it was recommended to swallow a small amount of water according to the previous instructions.

Food swallowing - when it was found that the patient had swallowed water under controlled conditions without effort or tension of the facial muscles, it was recommended to swallow small pieces of solid food according to the instructions given above.

Duration of education how to swallow and how to develop self-monitoring and automation of the proper way of swallowing and tongue resting position depends on the 
Poza opisanymi ćwiczeniami w zakresie ćwiczeń narządu żucia zalecano stopniowe przyjmowanie chrupków kukurydzianych - odgryzanie kęsów siekaczami, przesuwanie językiem w kierunku zębów przedtrzonowych i trzonowych, przeżuwanie, połykanie, po wcześniejszym przećwiczeniu tych czynności w gabinecie. Po kilku dniach wprowadzono jedzenie w podobny sposób słonych paluszków, zwracając szczególną uwagę na to, że pokarm jest stosunkowo twardy i żucie musi być bardzo uważne. Zalecono zjadanie kilku paluszków codziennie, zaznaczając, że należy to robić bez użycia rąk, przytrzymując je tylko wargami. Taka rehabilitacja jest przez pacjentów lubiana, nie kojarzy się z ćwiczeniami logopedycznymi, a bardzo dobrze wpływa na usprawnienie warg, żuchwy, języka i osiągnięcie prawidłowej kinestezji narządu żucia.

Zwrócono uwagę pacjentce na to, aby nie eliminowała ani nie unikała przyjmowania twardych pokarmów.

\section{Ćwiczenia oddechowe}

Wykonywane na stojąco - mają głównie na celu uruchomienie przepony; na siedząco - wypracowywanie umiejętności kierowania strumienia powietrza. Są też podstawą każdych ćwiczeń logopedycznych, gdyż m.in. wzmacniają kinestezję oralną. Od nich można też rozpocząć terapię szczękościsku. Dzięki nim wypracowuje się i utrwala właściwy tor oddechowy. Do poprzednich ćwiczeń oddechowych dodano:

- ćwiczenia toru przeponowego, wykonywane najpierw na leżąco, potem na stojąco: unoszenie powłok brzusznych na wdechu, a obniżanie na wydechu (wdech i wydech nosem, następnie wdech nosem, wydech ustami).

Po maksymalnie 10 ćwiczeniach oddechowych zalecono wykonywanie innego rodzaju ćwiczeń, np. języka lub warg, by nie dopuścić do hiperwentylacji.

\section{Diagnoza logopedyczna dwa lata po operacji}

- Wymowa pacjentki była w pełni zrozumiała, przy czym stwierdzono:

- zaburzenie artykulacji polegające na bocznej obustronnie wymowie głosek s, z, c, dz odnotowano zatem zmianę rodzaju zniekształcenia głosek w stosunku do okresu przed operacją, ale poprawę brzmienia;

- prawidłową wymowę głosek t, d, n - (poprawa);

- ustąpienie szczękościsku, szczególnie zauważalnego po operacji, najprawdopodobniej bezpośrednio spowodowanego długotrwałym noszeniem wyciągów międzyszczękowych; dzięki ćwiczeniom i samokontroli poprawa została odnotowana po ponad roku od zabiegu.

- Właściwy sposób oddychania.

- Ułożenie języka podczas połykania prawidłowe, choć pełna automatyzacja została odnotowana performance of articulatory organs, oral kinesthesia, motivation and frequency of exercise. In motivated adult patients it lasts from a few weeks to several months, most frequently (12).

Apart from exercises such as exercises for the masticatory organ described above, it was recommended to eat corn puffs gradually - biting fragments off with incisors, moving them with the tongue towards premolars and molars, chewing, swallowing, after having practiced these activities at the medical office. After a few days it was recommended to eat salty sticks in a similar way, paying particular attention to the fact that the food is relatively hard and chewing must be very precise. It was recommended to eat several sticks daily, but while paying attention that this should be done without using one's hands and holding sticks only with one's lips. Such rehabilitation is favoured by patients, it is not associated with speech therapy exercises, and it has a very good effect on the improved performance of lips, mandible, tongue and it helps achieve proper kinesthesia of the masticatory system.

The patient's attention was drawn to the fact that she should not eliminate or avoid consuming hard food.

\section{Respiratory exercises}

Performed in a standing position - they are mainly aimed at activating the diaphragm; in a seating position - developing abilities to direct the airflow. They are also the basis for any speech therapy exercises, as they strengthen oral kinesthesia, among other things. Treatment for lockjaw can also start with such exercises. A proper breathing route can be developed and maintained with these exercises. Previous respiratory exercises were supplemented with the following:

- $\quad$ exercises for the diaphragm route, at first performed when lying down, then standing up: lifting the abdominal muscles on inhalation, and lowering on exhalation (inhalation and exhalation via the nose, then inhalation via the nose, exhalation via the mouth).

After a maximum of 10 respiratory exercises, it was recommended to do other exercises, e.g. for the tongue or lips, in order to prevent hyperventilation.

\section{Speech therapy diagnosis two years after surgery}

- The patient's pronunciation was fully understandable and the following were found:

- articulation disorder consisting in the lateral pronunciation of phonemes $\mathrm{s}, \mathrm{z}, \mathrm{c}, \mathrm{dz}$ on both sides - therefore, the type of phoneme distortion changed in relation to the preoperative period, but the sound improved;

- correct pronunciation of phonemes $t, d, n-$ (improvement);

- regression of lockjaw, which was particularly noticeable after the surgery, and it was most probably directly related to the prolonged use of intermaxillary traction; thanks to exercises and 
M. Orzelska-Blomberg et al.

dopiero po dwóch latach (rok po zabiegu pacjentka prawidłowo połykała tylko w sytuacji świadomej kontroli).

- Ułożenie języka w spoczynku: koniec języka przy górnych zębach - pozycja wysoka według opisu Artese i in. - poprawa w stosunku do stanu wcześniejszego (7).

\section{Dyskusja}

Opisywane aktywne leczenie ortodontyczne trwało 2 lata i 3 miesiące (od marca 2015 do lipca 2017 roku). Terapia logopedyczna trwała dłużej, ze względu na kontrolę pozabiegową (grudzień 2015-wrzesień 2017, diagnoza kontrolna - październik 2018). W zakresie leczenia ortodontycznego rezultat oceniono na bardzo dobry. Uzyskano znaczną poprawę rysów twarzy, prawidłowy nagryz pionowy i poziomy, prawidłowe kontakty obu łuków zębowych. W zakresie terapii logopedycznej stwierdzono znaczną poprawę w zakresie artykulacji części głosek, zmianę sposobu niewłaściwej artykulacji części głosek, przy jednoczesnej poprawie ich brzmienia, oraz przejściową, trwającą około roku niepożądaną zmianę polegającą na mówieniu ze szczękościskiem.

Zauważono, że pacjentka chętniej angażuje się w systematyczną terapię logopedyczną, jeśli usłyszy wyraźne wskazanie od ortodonty. Po osiągnięciu celu ortodontycznego opisywana pacjentka nie miała już motywacji do regularnej pracy z logopedą. Jej oczekiwania zostały w pełni zaspokojone, choć logopedzi widzieli możliwość dalszego doskonalenia artykulacji. Nadrzędny cel - wypracowanie prawidłowych funkcji języka związanych z połykaniem i ułożeniem spoczynkowym - został osiągnięty.

Brakuje opisów naukowych wyników leczenia ortodontyczno-chirurgicznego poważnych szkieletowych wad zgryzu na wymowę (5). Z punktu widzenia logopedów temat jest bardzo interesujący, ponieważ w żadnym innym wypadku (poza rozszczepami podniebienia i /lub warg oraz urazami) tak drastycznie nie zmieniają się warunki anatomiczne wpływające na artykulację (przy braku zmian w centralnym układzie nerwowym).

W dotychczasowych badaniach podkreślano poprawę artykulacji po operacjach ortognatycznych, ale wzmiankowane są także przypadki braku zmiany sposobu wymowy, jak i jej pogorszenia $(5,13,14,15)$. Z punktu widzenia ortodontycznego reedukacja przez terapię logopedyczną może wpływać na stabilizację wyników leczenia (15).

Autorki niniejszego opracowania uważają, że w przypadku współwystępowania wady zgryzu z wadą wymowy niezbędna jest ścisła korelacja leczenia ortodontycznego z terapią logopedyczną. Z taką opinią zgadzają się inni autorzy (1, 2, $3,15)$. Jeśli u pacjenta stwierdza się obniżenie sprawności motorycznej narządu żucia, logopeda powinien zlecić odpowiednio dobrane ćwiczenia, by pomóc pacjentowi wypracować umiejętność prawidłowych funkcji fizjologicznych układu stomatognatycznego, takich, jak self-monitoring, improvement was noted more than a year after the surgery.

- $\quad$ Proper breathing route.

- The position of the tongue while swallowing was correct, although full automation was noted only two years later (one year after the surgery the patient swallowed correctly only when she controlled it consciously).

- The tongue resting position: the tongue tip near the upper teeth - a high position as described by Artese et al. - improvement compared to the previous state (7).

\section{Discussion}

This active orthodontic treatment lasted 2 years and 3 months (between March 2015 and July 2017). Speech therapy lasted longer due to the postoperative follow-up (December 2015-September 2017, follow-up diagnosis - October 2018). Regarding orthodontic treatment, the outcomes were assessed as very good. Significant improvement of facial features, correct overbite and overjet, correct contacts of both dental arches were obtained. As far as speech therapy is concerned, the following were observed: significant improvement in the articulation of some phonemes, a change in the incorrect articulation of some phonemes with simultaneous improvement in their pronunciation, and an undesirable change consisting of speaking with lockjaw that was temporary, lasting about a year.

It was noticed that the patient was more willing to engage in systematic speech therapy if she received a clear recommendation from an orthodontist. After achieving an orthodontic goal, this patient was no longer motivated to work with a speech therapist on a regular basis. Her expectations were fully met, although speech therapists saw the possibility of further improvement of articulation. The primary goal of developing correct functions of the tongue related to swallowing and resting position has been achieved.

There are no scientific descriptions of the outcomes of orthodontic and surgical treatment of serious skeletal malocclusions in relation to pronunciation (5). From the point of view of speech therapists, the subject is very interesting, because in no other case (except for clefts of the palate and/or lips and injuries) anatomical conditions affecting articulation change so drastically (with no changes in the central nervous system).

Previous studies have highlighted improved articulation after orthognathic surgeries, but there are also cases showing no changes in pronunciation, as well as its deterioration $(5$, $13,14,15)$. From an orthodontic point of view, re-education through speech therapy may have an impact on the stabilisation of treatment outcomes (15). 
połykanie czy ułożenie języka w spoczynku. Konieczne jest też wypracowanie właściwego toru oddechowego podczas oddychania statycznego, czyli nosem. Dzięki temu można łatwiej uzyskać właściwe ułożenie języka w spoczynku, a w konsekwencji - prawidłowe połykanie $(2,11,12)$.

U niektórych pacjentów prawidłowy tor oddychania można wypracować przed operacją, u innych należy to zrobić niezwłocznie po operacji. Przeszkodami mogą być skrzywienie przegrody nosa lub alergia i jeśli te przeszkody nie zostaną usunięte, uzyskanie celu może być utrudnione lub niemożliwe. Niektórzy pacjenci przed operacją ortognatyczną nie mają warunków anatomicznych do poprawnego wykonywania czynności połykania, żucia czy gryzienia.

W okresie przed operacją właściwe jest wprowadzenie ćwiczeń oddechowych, ćwiczeń motoryki żuchwy, warg, języka, ewentualnie ćwiczeń połykania, o ile pacjent może swobodnie dotykać końcem języka do podniebienia w okolicy wału dziąsłowego.

Po uzyskaniu optymalnych warunków zgryzowych możliwe jest ćwiczenie odgryzania, żucia i połykania. W tym celu należy wykonywać zlecone i pokazane przez logopedę ćwiczenia, które pacjent musi regularnie powtarzać codziennie samodzielnie, dbając o właściwą precyzję ich wykonania.

Bezpośrednio po zabiegu chirurdzy szczękowo-twarzowi zalecają pacjentom spożywanie pokarmów papkowatych, ale w miarę szybkie przyjmowanie pokarmów stałych i ich delikatne gryzienie, które pozwoli na szybszy powrót funkcji. Pacjenci jednak boją się to robić, a często nie wiedzą, jak.

Należy więc wytłumaczyć pacjentowi, które zęby pełnią jaką funkcję, pokazać na sobie - np. jedząc kawałek bułki - odgryzanie, żucie, rozszarpywanie i wskazać różnicę pomiędzy tymi czynnościami. Tłumacząc funkcję czynności żucia, nie wolno zapomnieć o tym, że bierze w niej udział również język, który przesuwa pokarm. Warto zwrócić uwagę, czy pacjent w podobny sposób wykorzystuje obie strony łuków zębowych, prawą i lewą, nie preferując jednej z nich.

Wskazane jest, aby pacjentowi wyjątkowo ostrożnemu zalecić stopniowe wprowadzanie coraz mniej rozdrobnionych pokarmów i etapowe dojście do pokarmów typu chleb ze skórką, kotlet schabowy czy hamburger. Przykładowo: przejście od zup warzywnych, przez rozgotowane warzywa, warzywa na parze, aż do warzyw twardych. Od owoców najbardziej miękkich, typu banan, do twardszych, typu jabłko, gruszka. Niektórzy pacjenci, mimo dorosłego wieku, nigdy w życiu takich pokarmów nie próbowali. Jedli np. wyłącznie tłuczone ziemniaki (puree), mięso mielone, rozgniecione, chleb bez skórki, pokrojony na drobne kawałki, itp. Ustalenie dotychczasowego sposobu przyjmowania pokarmu przez pacjenta może być bardzo pomocne w dalszej rehabilitacji funkcji motorycznych.
The authors of this paper believe that in the case of coexistence of a malocclusion with a speech defect, a close correlation between orthodontic treatment and speech therapy is necessary. This opinion is shared by other authors $(1,2,3,15)$. If the patient is found to have reduced motor functions of the masticatory organ, a speech therapist should recommend appropriately tailored exercises to help the patient develop correct physiological functions of the stomatognathic system, such as swallowing or placing the tongue at rest. It is also necessary to develop a proper breathing route during static breathing, i.e. via the nose. As a result, it is easier to obtain a proper tongue resting position and consequently, correct swallowing $(2,11,12)$.

In some patients a correct breathing route can be developed before the surgery, but in others it should be done immediately after the surgery. Obstacles can include deviation of the nasal septum or allergies, and if these obstacles are not removed, it may be difficult or impossible to reach the objective. Before the orthognathic surgery some patients do not have anatomical conditions for correct swallowing, chewing or biting.

In the period before the surgery it is recommended to introduce respiratory exercises, exercises for the motor functions of the mandible, lips, tongue, or swallowing exercises, provided that the patient can freely touch the palate near the alveolar ridge with the tongue tip.

When optimal occlusal conditions have been achieved, it is possible to practice biting off, chewing and swallowing. For this purpose, exercises ordered and shown by a speech therapist should be performed, and the patient must repeat them regularly every day on his or her own, paying attention to proper performance.

Immediately after the procedure, maxillofacial surgeons recommend that patients consume mushy foods, but as soon as possible they should start taking solid foods and chew them gently, as it will allow for a faster recovery. Patients; however, are afraid to do this and often do not know how to do it.

Therefore, it is necessary to explain to the patient which teeth perform what function, show this on oneself - e.g. while eating a piece of a bun - biting off, chewing, tearing, and indicate differences between these activities. When explaining chewing functions, it must not be forgotten that the tongue is also involved in this activity as it moves food. It is worth observing whether the patient uses both sides of dental arches, right and left, in a similar way, without preferring any of them.

It is advisable to recommend to a particularly cautious patient to gradually introduce less and less mushy food and to gradually consume such foods as bread with crust, pork cutlet or hamburger. For example, transition from vegetable soups, through cooked vegetables, steamed vegetables to hard vegetables. From the softest fruit, such as bananas, to harder fruit, such as apples, pears. Some patients, despite being adults, have never tried such foods in their lives. They consumed only mashed potatoes (puree), minced meat, crushed meat, bread 


\section{Wnioski}

1. Współpraca ortodontyczno-logopedyczna rozpoczęła się w okresie przygotowania pacjentki do zabiegu ortognatycznego i trwała przez cały okres przygotowawczy oraz pooperacyjny, aż do uzyskania stabilnych efektów satysfakcjonujących pacjentkę.

2. W ramach takiej współpracy najistotniejsza była reedukacja w zakresie funkcji fizjologicznych (oddychania, połykania, ułożenia języka w spoczynku) narządu żucia i zalecenia dotyczące sposobu przyjmowania pokarmów oraz poprawy artykulacji.

3. Autorki niniejszego opracowania uważają, że skorelowanie leczenia ortodontyczno-chirurgicznego $\mathrm{z}$ terapią logopedyczną jest korzystne dla pacjenta.

4. Zauważono, że pacjent chętniej angażuje się w systematyczną terapię logopedyczną, jeśli usłyszy wyraźne wskazanie od ortodonty.

5. Przedstawione przykładowe ćwiczenia logopedyczne ukazano wraz z ich opisem, ponieważ ortodonta nie zawsze ma możliwość stałej współpracy z logopedą. Intencją autorek było wskazanie potrzeby tych ćwiczeń i umożliwienie ich zalecenia oraz zastosowania również przez samych ortodontów. without crust, cut into small pieces, etc. Regarding further rehabilitation of motor functions, it may be very helpful to determine a method of food intake by the patient used so far.

\section{Conclusions}

1. Cooperation between an orthodontist and speech therapist began when the patient was prepared for the orthognathic procedure and lasted throughout the whole preparation and postoperative period, until stable outcomes satisfactory to the patient were achieved.

2. The most important part of such cooperation included re-education regarding physiological functions (breathing, swallowing, tongue resting position) of the masticatory organ and recommendations concerning the method of food intake and improvement of articulation.

3. The authors of this study believe that correlation of orthodontic and surgical treatment with speech therapy is beneficial for patients.

4. It was noticed that patients were more willing to engage in systematic speech therapy if they received a clear recommendation from an orthodontist.

5. These presented examples of speech therapy exercises are shown together with their descriptions, because an orthodontist is not always able to cooperate with a speech therapist on a regular basis. The authors wanted to indicate the need to introduce these exercises and to enable their recommendation and use also by orthodontists themselves.

9. Cuozzo G. Hyoid positioning during deglutition following forced posistioning of the tongue. Am J Orthod Dentofacial Orthop 1975; 68: $564-70$.

10. Gobeille D. Hyoid and muscle changes following distal repositioning of the tongue. Am J Orthod Dentofacial Orthop 1973; 70: 282-9.

11. Mackiewicz B. Wskazówki do nauki prawidłowego połykania w wadach zgryzu i wymowy u dzieci, w: Rocławski B. (red.) Opieka logopedyczna od poczęcia. Glottispol 1998: 77-83.

12. Pisulska-Otremba A. Reedukacja, w: Rocławski B. (red.) Opieka logopedyczna od poczęcia. Glottispol 1998: 53-67.

13. Ruscello DM, Tekieli ME, Jakomis T, Cook L, Van Sickels JE. The effects of orthognatic surgery on speech production. Am J Orthod Dentofacial Orthop 1986; 89: 237-43.

14. Hu W, Zhou Y, Fu M. Effect of skeletal Class III malocclusion on speech articulation. Chin J Stomatol 1997; 32: 344-6.

15. Gallerano G, Ruoppolo G, Silvestri A. Myofunctional and speech rehabilitation after orthodontic-surgical treatment of dentomaxillofacial dysgnathia. Progress in Orthodontics 2012; 3: 57-68.

8. Brodie A. Anatomy and physiology of head and neck musculature. Am J Orthod Dentofacial Orthop 1950; 11: 831-44. 